\title{
ANTI-MONEY LAUNDERING POLICIES IN THE FINANCIAL SECTOR
}

\author{
Vania Nestorova ${ }^{1}$
}

DOI: https://doi.org/10.31410/LIMEN.2019.89

\begin{abstract}
Money laundering is one of the most significant risks that threaten the financial systems at national and international level. Efforts to curb this phenomenon have a history of about thirty years and have undergone major developments. In condition of expanding of the globalization into various spheres of economic and social life and the rapid pace of entering of the technology, the dynamics in the development of the anti-money laundering policies reflects the need for greater protection of countries' financial systems against the entry of criminally acquired funds and for better risk management. This presentation traces the updating of international standards for combating money laundering in the last decade and their upgrading with new measures, which to meet the challenges of nowadays reality. Objects of analysis are the policies of particular importance for financial institutions, which aim to ensure the stability of financial systems. The Standards of the Financial Action Task Force, as well as the $4^{\text {th }}$ and $5^{\text {th }}$ Directives of the European Union, are considered as main accents of the paper.
\end{abstract}

Keywords: Money laundering, Financial systems, Preventive measures.

\section{INTRODUCTION}

$\mathrm{T}$ he legalizing of criminal assets is one of the main ways, facilitating the criminal entities to continue and to expand their criminal activity. The legalizing of such funds gives also advantage to criminal groups to entry the legal economic market, jeopardizing the existence of normal effective competition. Insofar the fair competition is at the heart of the stable market economy and creates conditions for development of the productivity and innovations, the reduction of competitive participants in the market is a prerequisite for reducing the viability of the economy, the sustainability of the social system and for lowering the standard of living of civil society. In addition to unfair competition, in a study B. Unger et al. ${ }^{2}$ accept as possible for the economy numerous short-term risks from the money laundering, including distortion of the economic performance, the investments, consumption and savings; changes in imports and exports, increasing volatility in interest rates and exchange rates, as well as in cash flows. As a long-term effect the researchers count expanding the criminal presence in the economy, changes in foreign investment, influencing the reliability of the financial sector, etc.

\section{DEVELOPMENT OF LEGISLATION TO COUNTER THE THREATS TO THE FINANCIAL SYSTEM OF MONEY LAUNDERING}

Peter Lilly (2006) says that "the first key to the world of money laundering is to get a bank account or at least get into the banking system. " The vulnerability of the financial systems to

$1 \quad$ University of National and World Economy, Student Town, Sofia, Bulgaria

$2 \quad$ Unger B., Rawlings G., Siegel M., Ferwerda J., de Kruijf W., Busuioic M., Wokke K. (2006). The amounts and the Effects of Money Laundering, Report to the Dutch Ministry of Finance Utrecht school of Economics, Utrecht School of Economics, The Netherlands

$3 \quad$ Lilley P., 2006. Dirty dealing. The untold truth about global money laundering, international crime and terrorism, Cogan page ltd, UK 
money laundering was identified in the second half of the XX century. Despite that money laundering has been criminalized in the $80 \mathrm{~s}$, measures for counteractions of that phenomenon have been taken in U.S. a decade earlier. In the 1970, the U.S. Congress passed the Bank Secrecy Act (BSA), also known as the Currency and Foreign Transactions Reporting Act. Under the BSA, financial institutions are required to assist the government agencies in detecting and preventing money laundering. BSA envisages these institutions to submit some kinds of reports as Currency Transaction Reports (CTR), Suspicious Activity Report (SAR), Foreign Bank Account Report (FBAR) etc. for each cash transactions exceeding $\$ 10,000$ (daily aggregate amount), for suspicious activity that might signal criminal activity (e.g. money laundering, tax evasion), to keep records of cash purchases of negotiable instruments etc.

In 1988, the Basel Committee on Banking Supervision also signalized for this threat in its Declaration "To prevent the use of the banking system for the purpose of money laundering". The huge negative effects from money laundering, in particular when the banking systems have been involved in such activity, motivated the countries for common answer to this phenomenon. As a result of the international efforts, in 1989 a special intergovernmental body - Financial Action Task Force (FATF), was created with the aim to develop and implement anti-money laundering policies at international level. Next year (1990), FATF presented 40 Recommendations, which serve as international standards, outlining the framework for the measures that have to be taken at national level 22 of those recommendations are targeted to the financial sector.

The globalization of the world economy by facilitating the cross-border movement of goods and capital, as well the development of technology, has also increased the opportunities to transfer criminally acquired assets through the national and global financial systems, including for their introduction into the formal economy as a legal financial resource. In 1996, the International Monetary Fund estimated the flow of globally laundered money between 2\% and 5\% of world Gross Domestic Product. United Nations Office on Drugs and Crime estimates that the total amount of criminal proceeds generated in 2009, excluding those derived from tax evasion, may have been approximately $\$ 2.1$ trillion, or 3.6 per cent of GDP in that year (2.3 to 5.5 percent) ${ }^{4}$. According to the report, of that total, the proceeds of transnational organized crime may have amounted to 1.5 per cent of global GDP, and 70 per cent of those proceeds are likely to have been laundered through the financial system. These new threats and the scale of profits from national and transnational organized crime, forced the revision of the existing FATF standards, which was made in 2012. For their updating, Giancarlo Del Bufalo, the President of FATF, points out that the revised Recommendations include requirements for stronger safeguards in the financial sector, strengthened law enforcement tools and improved international cooperation. ${ }^{5}$

Some of the main changes of the FATF Recommendations in the area of the protection of the financial system are related to:

- an enhanced risk-based approach, which enables countries and the private sector to apply their resources more efficiently by focusing on higher risk areas;

- improved transparency to make it harder for criminals and terrorists to conceal their identities or hide their assets behind legal persons and arrangements;

- stronger requirements when dealing with politically exposed persons (PEPs) etc.

\footnotetext{
$4 \quad$ UNODC report: Estimating illicit financial flows resulting from drug trafficking and other transnational organized crimes

$5 \quad$ FATF. FATF steps up the fight against money laundering and terrorist financing, FATF Recommendations 2012, Press Handout, Paris, 16 February 2012
} 
The revised standards are also at the heart of the measures taken by the European Union to update Community legislation, both in the area of prevention and prosecution of money laundering. At that moment, regulative measures for protection of financial systems are envisaged in some EU acts, but those measures are no longer comprehensive enough to respond to the current threats. In April 2015, the European Commission (EC) presented through a Communication to the European Parliament, the Council of the EU, the European Economic and Social Committee and the Committee of the Regions its European Security Plan. In that document, place among the other threats to the security (terrorism, cybercrime etc.) is assigned to the organized crime networks, operating at the territory of the Union, and their main purpose - the profit. Considering that international criminal networks use legal business structures to conceal their source of criminal profits, the attention in the plan is drawn to the need to take actions against infiltration of the organized crime into the legitimate economy. Appropriate in this line measures the Commission proposed through new legislative suggestions, part of which - the Fourth anti-money laundering package.

\section{ACCENTS IN DIRECTIVE (EU) 2015/849}

Significant step to make the EU's anti-money laundering efforts more effective is the adopted in May 2015 Fourth anti-money laundering package (Directive (EU) 2015/849 and Regulation (EU) $\left.2015 / 847^{6}\right)$. Compared to the existing at that moment Community regulation, the $4^{\text {th }} \mathrm{Di}$ rective introduces serious measures for the security of financial systems. Some of the main initiatives include:

- Establishing of national registers of beneficial owners, the information in which will be made available to national authorities and obliged entities. The measure is provided to facilitate the identification of any natural person who exercises ownership or control over a legal entity. In order to ensure effective transparency, the widest possible range of legal entities, established or created by any other mechanism within the territory of the member states, have to be covered.

- Introducing an obligation for Member States to assess regularly the national risk of money laundering (and supranational by the EU Commission). The results of the national risk assessments require to be made available to the obligated entities in appropriate way and in a timely manner, so that they can identify, understand, manage and mitigate their own risks.

- Establishing of coherent policy towards third countries with deficits in their regulatory regimes to counter money laundering and terrorist financing.

- Enhancing the requirements to the obliged entities (incl. financial institutions) for implementing a comprehensive, risk-based approach, based on objective data in order to deal more effectively with the risks of money laundering and terrorist financing. The Directive counts that the criminals use the new technologies as new and innovative ways for money laundering, so that requires they the later to be taken into account in the risk assessment.

- Increasing the requirements to the obliged entities to perform enhanced due diligence to clients, who perform or have performed important public functions in the country or abroad, as well as in relation to senior positions in international organizations.

Directive (EU) 2015/849 of the European parliament and of the Council of 20 May 2015 on the prevention of the use of the financial system for the purposes of money laundering or terrorist financing, amending Regulation (EU) No 648/2012 of the European Parliament and of the Council, and repealing Directive 2005/60/EC of the European Parliament and of the Council and Commission Directive 2006/70/EC// Regulation (EU) 2015/847 of the European Parliament and of the Council of 20 May 2015 on information accompanying transfers of funds and repealing Regulation (EC) No 1781/2006, both OJ L 141, 5.6.2015 
- Clarifying the requirement, relevant to the necessary approval from senior management for establishing business relationships. ${ }^{7}$.

- Introducing requirement competent authorities to provide feedback to obligated entities on the usefulness and follow-up of their suspicious transaction reports.

- Reminding to obligated entities to put in place effective systems that allow them to have full and timely access, through secure and confidential channels, to information on business relationships they maintain or have maintained with certain individuals. The Directive encourages Member States to introduce banking registry systems or electronic data, that would give FIUs access to bank account information, without need for judicial authorization where it is applicable.

And before the deadline for transposition of the $4^{\text {th }}$ Directive to be finished, the European Commission made the next major step in countering money laundering at Community level. In February 2016, the Commission presented an Action Plan to strengthen the fight against terrorist financing, envisaging new counter-measures, including to financial systems. According Valdis Dombrovskis - vice-president of EC, the legislative proposals aim to improve the oversight of the many financial means used by terrorists, from cash and cultural artefacts to virtual currencies and anonymous pre-paid cards, while avoiding unnecessary obstacles to the functioning of payments and financial markets for ordinary, law-abiding citizens ${ }^{8}$.

\section{THE NEW DIRECTIVE (EU) 2018/843}

In July 2018, Directive 2018/843/ EU ${ }^{9}$ - the Fifth Anti-Money Laundering Directive, is already a fact ${ }^{10}$. The same year a new Regulation for improving the control of cash imported into and exported to and from the EU, as well as a Directive on combating money laundering by criminal law were also adopted. The Fifth Directive significantly improves the Community framework in the fight against money laundering, extending the scope of the Fourth one in several main areas:

- Increases transparency about beneficial owners of companies. The information contained in the beneficial owner registers is required to be public and the Commission have to ensure all national registers to be linked to10th of March 2021. In order to ensure legal certainty and a level playing field, Member States are required to notify the Commission of the categories, description of the characteristics, names and where applicable legal basis for the trusts and similar legal arrangements on their territory. Consolidated list of such trusts and similar legal arrangements will be published by EC in the Official Journal of the EU in order to facilitate their identification by other Member States.

- Includes new groups of obliged entities.

- Expands the scope of the enhanced due diligence to the virtual currency trading platforms and virtual wallet providers, offering greater anonymity in financial transfers.

\footnotetext{
$7 \quad$ The Directive envisage that such approval may be granted by persons with sufficient knowledge of the institution's risk exposure to money laundering and terrorist financing and a sufficiently high ranking to make decisions concerning that risk exposure

8 Commission presents Action Plan to strengthen the fight against terrorist financing. EU Commission, Press release. February 2016.Strasbourg, available at: https://ec.europa.eu/commission/presscorner/detail/en/ IP 16 202

9 Directive (EU) 2018/843 of the European Parliament and of the Council of 30 May 2018 amending Directive (EU) $2015 / 849$ on the prevention of the use of the financial system for the purposes of money laundering or terrorist financing, and amending Directives 2009/138/EC and 2013/36/EU OJ L 156, 19.6.2018 The time for its transposition expired on 10 January 2020.
} 
The Directive provides harmonized definitions of "virtual currency" and "custodian wallet provider".

- Limits further the anonymity of prepaid cards, reducing the identification threshold from $€ 250$ to $€ 150$.

- Introduces safeguards in relation to financial flows from and to high-risk third countries. The Commission is empowered to adopt delegated acts in order to identify highrisk third countries, taking into account different aspects, described in the Directive.

- Requires Member States to put in place centralized automated mechanisms, such as central registries or central electronic data retrieval systems, which allow the identification, in a timely manner, of any natural or legal persons holding or controlling payment accounts, bank accounts (identified by IBAN) and safe-deposit boxes, held by a credit institution within their territory. Member States are required to notify the Commission of the characteristics of those national mechanisms.

\section{NEXT INITIATIVE}

Recognizing that the harmonized measures adopted at Community level are not always effectively implemented by the Member States, in the light of the new rules the Commission draws attention also to additional measures to strengthen the supervision of financial institutions. In 2017, a Proposal ${ }^{11}$ to amend the Regulation, establishing the European Banking Authority (EBA), was made by the Commission with a view to enhance EBA's role in the supervision of the financial sector. Through the amendments, EBA will be the primary supervisory authority overseeing compliance with Community law by national supervisory authorities. According to the position, approved by the Council of the $\mathrm{EU}^{12}$, it is expected EBA to be entrusted for collecting of information from national competent authorities on weaknesses, identified in the context of their activities of preventing or money laundering and financing of terrorism; for improving the quality of supervision by drawing up common standards and coordination between national supervisors; conducting risk assessments for the competent authorities on their strategies and resources to counter the most important emerging threats in the area concerned etc.

\section{CONCLUSION}

The review of the international standards and European legislation shows that the topic of preventing the use of financial systems for money laundering stays active on the agenda of the international and European institutions. The changing nature of money laundering threats, facilitated by a permanent evolution of technology and of the variety of means, using by criminals

11 Proposal for a Regulation of the European parliament and of the Council amending Regulation (EU) No 1093/2010 establishing a European Supervisory Authority (European Banking Authority); Regulation (EU) No 1094/2010 establishing a European Supervisory Authority (European Insurance and Occupational Pensions Authority); Regulation (EU) No 1095/2010 establishing a European Supervisory Authority (European Securities and Markets Authority); Regulation (EU) No 345/2013 on European venture capital funds; Regulation (EU) No 346/2013 on European social entrepreneurship funds; Regulation (EU) No 600/2014 on markets in financial instruments; Regulation (EU) 2015/760 on European long-term investment funds; Regulation (EU) 2016/1011 on indices used as benchmarks in financial instruments and financial contracts or to measure the performance of investment funds; Regulation (EU) 2017/1129 on the prospectus to be published when securities are offered to the public or admitted to trading on a regulated market; and (EU) Directive 2015/849 on the prevention of the use of the financial system for the purposes of money-laundering or terrorist financing [doc. 12111/18 - COM(2018) 646 final]

12 Council of EU. Financial supervision: Council presidency and Parliament reach provisional deal on supervisory framework for European financial institutions, Press release, 21 March 2019 
for legalizing of their criminal money, requires continuous adaptation of the legal framework in order to address efficiently existing risks.

The revision of the FATF Recommendations and the following-up more extensive and more comprehensive legislative and organizational measures, are a clear proof that the efforts to curb money laundering are and will continue to be an essential part of the common measures, design to guarantee the security of the financial systems and to prevent new threats from arising.

\section{REFERENCES}

Lilley P. (2006). Dirty dealing. The untold truth about global money laundering, international crime and terrorism, Cogan page ltd, UK

Unger B., Rawlings G., Siegel M., Ferwerda J., de Kruijf W., Busuioic M., Wokke K. (2006). The Amounts and the Effects of Money Laundering, Report to the Dutch Ministry of Finance Utrecht school of Economics, Utrecht School of Economics, The Netherlands

Council of the EU. Financial supervision: Council presidency and Parliament reach provisional deal on supervisory framework for European financial institutions, Press release, 21 March 2019. Available at:

https://www.consilium.europa.eu/en/press/press-releases/2019/03/21/financial-supervision-council-presidency-and-parliament-reach-provisional-deal-on-supervisory-framework-for-european-financial-institutions/

EU Commission. Commission presents Action Plan to strengthen the fight against terrorist financing, Press release. February 2016. Available at: https://ec.europa.eu/commission/presscorner/detail/en/IP_16_202

FATF. FATF steps up the fight against money laundering and terrorist financing, FATF Recommendations 2012, Press Handout, Paris, 16 February 2012, Available at:

https://www.fatf-gafi.org/publications/fatfrecommendations/documents/fatfstepsupthefightagainstmoneylaunderingandterroristfinancing.html

UNODC report: Estimating illicit financial flows resulting from drug trafficking and other transnational organized crimes. October 2011. Available at:

https://www.unodc.org/unodc/en/frontpage/2011/October/illicit-money_-how-much-isout-there.html 